\title{
Studi Tentang Tingkat Kesegaran Jasmani Siswa Kelas V Sekolah Dasar Negeri 11 Pasakiat Taileleu Kecamatan Siberut Barat Daya Kabupaten Kepulauan Mentawai
}

\author{
Zainal $^{1}$, Zainul Johor ${ }^{2}$ \\ Fakultas Ilmu Keolahragaan, Universitas Negeri Padang \\ E-mail: zainal@,gmail.com ${ }^{1}, \underline{\text { zainul1956@,fik.unp.ac.id }}{ }^{3}$
}

\begin{abstract}
Abstrak
Masalah dalam penelitian ini yakni tingkat kesegaran jasmani siswa Sekolah Dasar Negeri 11 Pasakiat Taileleu kurang baik atau masih rendah, sedangkan tujuan dari penelitian ini untuk mengetahui tingkat kesegaran jasmani siswa Sekolah Dasar Negeri 11 Pasakiat Taileleu.

Penelitian ini merupakan penelitian deskriptif, yakni untuk mengungkapkan tingkat kesegaran jasmani siswa Sekolah Dasar Negeri 11 Pasakiat Taileleu. Teknik pengambilan sampel menggunakan Purposive Sampling yakni menggunakan siswa kelas V yang berjumlah 28 orang. Teknik pengambilan data dengan melaklukan tes kesegaran jasmani berupa: tes lari $30 \mathrm{~m}$, gantung siku tekuk, baring duduk, lompat tegak dan lari 600 meter.

Teknik analisis dalam penelitian ini adalah $P=F / N \times 100 \%$. Berdasarkan hasil penelitian di Sekolah Dasar Negeri 11 Pasakiat Taileleu didapatkan hasil yakni sebanyak 18 orang (64,3\%) kesegaran jasmaninya sedang, dan 10 orang $(35,7 \%)$ tingkat kesegaran jasmaninya kurang. Jadi sudah diproses ditemukan bahwa tingkat kesegaran jasmani siswa Sekolah Dasar Negeri 11 Pasakiat Taileleu masih sedang.
\end{abstract}

Kata Kunci: Kesegaran Jasmani

The problem in this study is the level of physical fitness of the elementary school students 11 Pasakiat Taileleu is not good or still low, while the purpose of this study is to determine the level of physical fitness of elementary school students 11 Pasakiat Taileleu.

This research is a descriptive study, which is to reveal the level of physical fitness of the students of State Elementary School 11 Pasakiat Taileleu. The sampling technique using Purposive Sampling is using class $V$ students, amounting to 28 people. The data collection technique is by carrying out physical fitness tests in the form of: 30 m running test, bending elbow hanging, lying down sitting, jumping upright and running 600 meters.

The analysis technique in this study is $P=F / N \times 100 \%$. Based on the results of the research in the State Elementary School 11 Pasakiat Taileleu the results were as many as 18 people (64.3\%) moderate physical fitness, and 10 people (35.7\%) the level of physical fitness was lacking. So that it has been processed it was found that the level of physical fitness of students of Public Elementary School 11 The taileleu is still underway

Keywords : physical fitness level

\section{PENDAHULUAN (10\%)}

Salah satu bidang yang memegang peranan penting untuk membangun manusia Indonesia seutuhnya adalah bidang pendidikan. Pendidikan Nasional yang berdasarkan Pancasila bertujuan untuk mencerdaskan kehidupan bangsa dan meningkatkan kualitas manusia indonesia sehat jasmani 
Sport Science: Jurnal Sain Olahraga dan Pendidikan Jasmani ISSN 114-562X (Cetak), ISSN XXXX-XXXX(Online)

http://sportscience.ppj.unp.ac.id/index.php/jss/index

dan rohani. Sebagaimana dinyatakan dalam Undang- undang Republik Indonesia No. 20 tahun 2003 pasal 3 tentang sistim Pendidikan Nasional bahwa:"Pendidikan nasional berfungsi mengembangkan kemampuan dan membentuk watak serta peradaban bangsa yang bermatabat dalam rangka mecerdaskan kehidupan bangsa, bertujuan untuk berkembangnya potensi peserta didik agar menjadi manusia beriman dan bertakwa kepada Tuhan Yang Maha Esa berakhlak mulia, sehat, berilmu, cakap, kreatif, mandiri dan menjadi warga negera yang demokratis serta bertanggung jawab".

Dari penjelasan di atas dapat dijelaskan bahwa pendidikan nasional berfungsi mengembangkan dan mencedaskan anak bangsa sehingga Negara tidak menjadi Negara yang terbelakang. Tujuan pendidikan jasmani dan kesehatan adalah untuk membantu siswa dalam meningkatkan kesegaran dan kesehatan melalui pengenalan penanaman sikap positif dan kesehatan serta kemampuan gerak dasar dari berbagai aktifitas jasmani.

Dengan tujuan ini semakin terlihat bahwa kesegaran jasmani adalah aspek penting dalam menghadapi suatu aktifitas. Adanya bidang studi pendidikan jasmani dan kesehatan di semua jenjang pendidikan diharapkan agar semua murid Sekolah, mempunyai kesegaran jasmani yang baik. Karena dengan tingkat kesegaran jasmani yang baik dapat menambah gairah kemapuan kerja, seperti yang diungkapkan oleh Kiram (1994) bahwa : "Peningkatan kesegaran jasmani merupakan suatu kemampuan yang menitik beratkan pada fungsi-fungsi fisiologis, anatomis dan psikis yaitu kemampuan jantung, pembuluh darah, paru dan otot yang berfungsi pada efisiensi kerja yang maksimal.

Sehingga dapat membantu kinerja organ tubuh untuk mendukung aktifitas jasmani anak didik". Materi penjasorkes dapat meningkatkan kesegaran jasmani anak maka sangat penting sekali bagi siswa untuk mengikuti pendidikan Penjas Orkes di sekolah. Berikutnya menurut Arsil (1999) bahwa "Kesegaran jasmani merupakan kamampuan fisik yang dapat berupa kemampuan arobic dan an arobic, diamana kemampuan tersebut dapat dilatih melalui program latihan yang terencana secara teratur dan berkesinambungan".

Kesegaran jasmani sangat dibutuhkan oleh anak didik untuk memperoleh ketangkasan, kesanggupan serta kemampuan belajar yang tinggi. Tingkat kesegaran jasmani akan membantu seorang dalam melaksanakan pekerjaan sehari-hari tanpa menimbulkan kelelahan yang berarti. Salah satu jalan untuk memelihara atau meningkatkan kesegaran jasmani adalah dengan melakukan olahraga yang benar dan aktifitas fisik sehari-hari yang bermanfaat untuk kesehatan, karena kesehatan sangat menetukan aktivitas seseorang.

Kesegaran jasmani juga tidak terlepas dari faktor makanan, karena bahan makanan diperlukan tubuh sebagai sumber energi, pembangun sel-sel tubuh, komponen biokatalisator dan metabolisme. Sehingga dapat membantu seseorang dalam beraktifitas dan tidak mudah lelah kerena terdapat keseimbangan antara makanan dengan energi yang dikeluarkan.

Sebagaimana yang dinyatakan oleh Lamb dalam Arsil (1999) bahwa :"Makanan harus sesuai dengan yang dibutuhkan oleh tubuh baik secara kuantitatif maupun kualitatif maksudnya adalah perbandingan jumlah karbohidrat, lemak dan protein yang dimakan harus sesuai dengan aktifitas seseorang sedangkan kualitatif maksudnya makanan mengandung bahan-bahan yang dibutuhkan tubuh seperti karbohidrat, lemak, protein, vitamin dan mineral dan air jumlahnya dapat diberikan lebih banyak jika diperlukan".

Penyimpulan dari kebutuhan makanan yang baik dan lengkap akan mempengaruhi faktor gizi dan kesehatan sehingga sangat membantu dalam setiap aktifitas yang dilakukan terutama dalam aktifitas jasmani, karena setiap aktifitas jasmani membutuhkan energi yang cukup dan seimbang. Banyak aspek yang menjadi faktor penunjang terciptanya kesegaran jasmani yang bagus mulai dari gizi, lingkungan dan kegiatan yang dilakukan seharusnya setiap perserta didik di bebagai tingkat jenjang pendidikan memiliki tingkat kesegaran jasmani yang bagus, sehingga pekerjaan yang awalnya sukar untuk dilakukan menjadi mudah tanpa mengalami kelelahan yang berarti. 
Apalagi peran serta pemerintah melalui penetapan pendidikan jasmani sebagai salah satu bidang studi di setiap jenjang pendidikan menjadi faktor pendukung terbentuknya jasmani yang sehat sehingga dapat mempertinggi gairah kerja yang menciptakan peserta didik yang sehat jasmani dan rohani. Berdasarkan observasi yang peneliti lakukan di lapangan. Peneliti menemukan beberapa masalah dari keadaan kesegaran jasmani siswa di sekolah, sekolah yang peneliti maksud adalah Sekolah Dasar Negeri 11 Pasakiat Taileleu.

Sekolah tersebut terletak di daerah Pantai desa Pasakiat Taileleu Kecamatan Siberut Daya. Siswa yang belajar di sekolah tersebut dimulai dari golongan rendah sampai menengah atas. Kemampuan intelegensi yang berbeda-beda menimbulkan beraneka ragamnya buah fikiran untuk memaknai suatu hal. Pikir-pikirkan tersebut bermunculan untuk memberikan pengertian tentang suatu objek yang dijadikan sebagai bahan dasar dalam ilmu pengetahuan.

Seperti makna kesegaran jasmani yang beraneka ragam. Terdapat banyak pengertian serta pendapat dari para ahli mengenai kesegaran jasmani seperti apa yang dikemukakan Sutarman (1975) menyatakan bahwa "kesegaran jasmani adalah aspek fisik dari kesegaran yang menyeluruh, memberikan kesanggupan kepada seseorang untuk menjalankan hidup yang produktif dan dapat menyesuaian terhadap stress fisik yang layak".

Dan hal ini yang penting untuk meningkatkan kesegaran jasmani adalah latihan dan olahraga yang teratur, tubuh memerlukan oksigen untuk memproduksi energi, tubuh tidak menyimpan oksigen. Oksigen harus diambil dan disalurkan keorgan-organ tubuh dan jaringan yang membutuhkan energi. Kemampuan tubuh untuk melakukan hal tersebut sangat tergantung dari tingkat kesegaran jasmani masing-masing individu. Bagi orang yang mempunyai tingkat kesegaran jasmani yang baik akan mudah untuk melakukan pengambilan oksigen yang dibutuhkan tubuh.

Bagi orang yang tingkat kesegaran jasmaninya rendah, hal ini merupakan suatu kesulitan yang berarti dengan kata lain orang yang banyak melakukan aktifitas dan olahraga yang teratur maka tingkat jasmaninya relatif baik dibanding dengan orang yang melakukan sedikit aktifitas jasmaninya. Tingkat kesegaran jasmani yang baik dapat membantu seseorang untuk menyelesaikan tugas sehari-hari dengan tidak menimbulkan kelelahan, kerena semakin tinggi tingkat kesegaran jasmani seseorang semakin tinggi pula kesanggupan dan kemampuannya.

Bagi siswa-siswa Sekolah Dasar (SD) yang sedang tumbuh, peranan kesegaran jasmani bukan saja untuk sekedar dapat melakukan tugas tetapi untuk dapat meningkatkan kemampuan belajar dengan baik. Mengingat pentingnya kesegaran jasmani, Lyckolat dalam Sutrisno (1987) mengemukakan komponen-komponen kesegaran jasmani dapat dikelompokan ke dalam dua golongan barikut: "Ada 2 komponen penting yang berkaitan dengan kesegaran jasmani yaitu (1) komponen yang berhubungan dengan kesehatan (health related fitness) meliputi daya tahan otot, kekuatan otot, kelentukan, komposisi tubuh, (2) komponen yang berhubungan dengan keterampilan (skill related) meliputi kelincahan, keseimbangan, koordinasi, kecepatan, tenaga/daya, waktu reaksi".

Komponen tersebut menjadi tolak ukur terciptanya tingkat kesegaran jasmani yang bagus, karena keadaan jasmani yang dikatakan baik apabila beberapa komponen tersebut dimiliki oleh seseorang yang digunakan dalam setiap aktifitasnya. Selanjutnya Hairy dan Ahady (1982) mengelompokkan unsur-unsur kesegaran jasmani sebagai berikut: "Ada beberapa unsur yang menjadi pendorong terbentuknya kesegaran jasmani diantaranya : (a) Kekebalan terhadap penyakit, (b) Kekuatan dan ketahanan otot, (c) Ketahanan Kardorespiratory, (d) Daya tahan otot, (e) Fleksibilitas, (f) Kecepatan, (g) Kelincahan, (h) Koordinasi, (i) Keseimbangan, (j) dan Ketepatan.

Unsur kekebalan penyakit merupakan faktor yang sangat penting. Seseorang yang sedang sempurna kesegaran jasmaninya berarti tubuhnya kebal terhadap penyakit keturunan dan penyakit yang sedang berjangkit di sekitar lingkungannya. Pakaian, istirahat, rekreasi, aktifitas fisik dan kebersihan. Sebagaimana yang dikemukakan oleh Rusli Lutan (2001) "seserorang yang memiliki kesegaran yang baik dan memiliki kekebalan terhadap penyakit dikarenakan aktifitas yang sering dilakukan". 
Sport Science: Jurnal Sain Olahraga dan Pendidikan Jasmani ISSN 114-562X (Cetak), ISSN XXXX-XXXX(Online)

http://sportscience.ppj.unp.ac.id/index.php/jss/index

Menurut Gusril (1994) menyatakan bahwa "kekuatan otot adalah kualitas yang memungkinkan terjadinya konstraksi sekelompok otot secara maksimal". Sedangkan Ring dalam Suharno (1986) menyatakan bahwa :daya tahan otot adalah kualitas yang membuat seseorang mampu menggerakan sekelompok otot secara berulang kali (dinamis) dibawah maksimal". Sedangkan Bombo dalam Suahrno (1986) menyatakan bahwa "daya tahan otot adalah kemampuan seseorang mempergunakan ototnya untuk berkontraksi secara terus menerus dalam waktu yang relatif lama".

Hal demikian menyebabkan hasil belajar siswa menjadi buruk. Faktor-faktor penyebab buruknya kesegaran jasmani siswa di Sekolah Dasar Negeri 11 Pasakiat Taileleu disebabkan karena kurangnya pasokan gizi yang dikonsumsi siswa di sekolah. Salah satu contohnya siswa lebih sering mengkonsumsi seperti kue, lontong dan sebagainya dari pada mengkonsumsi makanan bergizi. Masalah tersebut ada yang disebabkan karena siswa yang malas makan dan ada juga disebabkan karena rendahnya perekonomian keluarga siswa di rumah.

Rendahnya perhatian dinas kesehatan setempat juga merupakan salah satu faktor buruknya kesegaran jasmani siswa Sekolah Dasar Negeri 11 Pasakiat Taileleu. Tidak adanya kunjungan dan observasi pihak kesehatan kesekolah dapat membuat pihak sekolah tidak tahu dengan keadaan kesegaran jasmani siswanya. Sedikitnya kesempatan siswa untuk berolahraga juga merupakansalah satu penyebab buruknya kesegaran jasmani siswa di sekolah. Kurangnya perhatian guru penjas dalam mengajar sehingga siswa malas bergerak.

Sedikitnya kesempatan siswa bergerak dapat mempengaruhi burunya kesegaran jasmani siswa di sekolah sehingga motivasi siswa menjadi turun untuk belajar penjasorkes. Sehubungan dengan hal di atas maka penulis tertarik untuk melakukan penelitian mengenai tingkat kesegaran jasmani pada Sekolah Dasar (SD). Hal tersebut dimulai dari masalah yang peneliti lihat di lapangan terhadap kesegaran jasmani siswa Sekolah Dasar terutama pada Sekolah Dasar tempat peneliti mengajar.

Semua siswa hendaknya memiliki kesegaran jasmani yang baik, agar pelaksanaan proses pembelajaran dapat berjalan dengan baik. Masing-masing siswa yang berada pada beda daerah hendaknya kondisi fisiknya sama-sama baik. Berdasarkan masalah demikian maka sangat penting dilakukan penelitian yang berkaitan tentang kesegaran jasmani siswa di Sekolah Dasar Negeri 11 Pasakiat Taileleu.

\section{METODE}

Jenis penelitian yang dilakukan berbentuk deskriptif yaitu meninjau dan mendiskripsikan suatu keadaan pada saat penelitian dilakukan. Menurut dan Sudjana (1989), "Penelitian deskriptif adalah penelitian yang berusaha mendeskripsikan suatu gejala, peristiwa, kejadian yang terjadi saat sekarang". Selanjutnya Surakhman (1985), menyatakan bahwa "Metode deskriptif adalah metode yang memusatkan diri pada pemecahan masalah yang dilakukan dengan pengumpulan data, kemudian menganalisanya".

Dengan demikian lain penelitian deskriptif mengambil masalah atau memusatkan masalah-masalah aktual sebagaimana adanya pada saat penelitian dilaksanakan, Penelitian ini berlokasi di Sekolah Dasar Negeri 11 Pasakiat Taileleu. Sampel penelitian ini adalah siswa kelas 1- 6, sedangkan sampel seluruh kelas 4 dengan jumlah 28 orang dengan Teknik yang digunakan dalam pengambilan sampel adalah Teknik Pourposive sampling, yang merupakan pengambilan sampel bersyarat.

Teknik dan alat pengumpulan data dilakukan dengan Tes Kesegaran Jasmani Indonesia Usia 10-12 tahun sebagai berikut: 1) Tes lari cepat 30 meter, 2) Tes angkat tubuh, 3) Tes baring duduk, 4) Tes loncat tegak, dan Tes lari / jalan jarak 600 Meter. Teknik analisis data yang digunakan dalam penelitian ini adalah deskriptif, maka data yang terkumpul akan 
dianalisis menggunakan statistic deskriptif dengan tabulasi frekuensi, melalui rumus sebagai berikut dengan rumus :

$$
\begin{aligned}
& \text { Ket } \quad: \\
& \mathrm{P}=\text { persentase } \\
& \mathrm{F}=\text { frekuensi } \\
& \mathrm{N}=\text { sampel }
\end{aligned}
$$$$
\mathrm{P}=\mathrm{F} / \mathrm{N} \times 100 \%
$$

\section{HASIL DAN PEMBAHASAN \\ Hasil Penelitian}

Berdasarkan analisis yang telah di uraikan, maka dalam bagian ini akan dilakukan pembahasan hasil penelitian mengenai tingkat Kebugaran jasmani Siswa SD Negeri 11 Pasakiat Taileleu adapun pembahasan dari keadaan tingkat Kebugaran jasmani siswa diuraikan sebagai berikut: Dilihat secara keseluruhan keadaan tingkat Kebugaran jasmani Siswa SD Negeri 11 Pasakiat Taileleu yang diperoleh adalah 64,3\% temasuk dalam kategori sedang, dan 35,7\% termasuk dalam kategoti kurang.

Berdasarkan hasil tersebut jelas bahwa keadaan tingkat Kebugaran jasmani Siswa SD Negeri 11 Pasakiat Taileleu berada pada klasifikasi sedang. Kebugaran jasmani juga merupakan kemampuan tubuh seseorang untuk melakukan tugas, pekerjaan atau aktivitas sehari- hari tanpa menimbulkan kelelahan yang berarti. Menurut fox dan kawan- kawan (1987:6) menjelaskan bahwa "Kebugaran jasmani suatu kapasitas fisiologi atau fungsional yang memberikan suatu kapasitas yang meningkat.

Menurut Direktorat Jendral Pemuda dan Olahraga Departemen Pendidikan Nasional Indonesia (2003) tentang pentingnya kesegaran jasmani bagi pelajar, bahwa "apa yang dicapai dalam bidang akademis ada hubungan erat dengan kondisi badan, telah dibuktikan bahwa pelajar-pelajar yang kesegaran jasmaninya diatas rata-rata pencapaian akademisnya bagus".

Kebugaran jasmani diberi arti sebagai aspek kualitas hidup yang sangat berhubungan dengan keadaan status jasmani yang positif, Kebugaran jasmani merupakan sari utama atau cikal bakal dari Kebugaran secara umum". Jadi apabila seseorang dalam keadaan segar salah satu aspek pokok yang nampak adalah penampilan jasmaninya. Dengan demikian dengan adanya teori tersebut dapat disimpulkan bahwa dengan kategori sedang dan kurang tingkat Kebugaran jasmani Siswa SD Negeri 11 Pasakiat Taileleu, akan mengakibatkan keadaan fisiologi tubuh akan menurun, dan tentu saja itu akan mempengaruhi semua aktivitas yang dijalankan oleh siswa tersebut.

Kesegaran jasmani yang baik merupakan milik yang berharga bagi setiap murid, pelajar, siswa dan masyarakat dalam menjalankan kehidupan sehari-hari. Dan salah satu jalan untuk mendapatkan kesegaran jasmani yang baik itu, yaitu dengan melaksanakan olahraga secara rutin dan teratur. Pemerintah menyadari betapa pentingnya kesegaran jasmani bagi anak didik dan masyarakat sehingga pada saat ini di setiap jenjang pendidikan diwajibkan untuk melaksanakan kegiatan pendidikan jasmani dan kesehatan yang bertujuan untuk membina jasmani dan rohani anak didik sehingga dapat menunjang prestasi belajar sehingga menjadi lebih baik.

\section{Pembahasan}


Sport Science: Jurnal Sain Olahraga dan Pendidikan Jasmani ISSN 114-562X (Cetak), ISSN XXXX-XXXX(Online)

http://sportscience.ppj.unp.ac.id/index.php/jss/index

Temuan penelitian ini juga dipertegas oleh pendapat Sutarman dalam Arsil (1999) yang mengatakan "Kebugaran jasmani adalah suatu aspek fisik dari Kebugaran yang menyeluruh (total fitnes), yang memberikan kesanggupan kepada seseorang untuk menjalani hidup yang produktif dan dapat menyesuaikan diri dari pada tiap- tiap perubahan fisik (psycal stress) yang layak". Disini berarti Kebugaran jasmani merupakan cermin dari kemampuan fungsi sistem- sistem dalam tubuh yang dapat mewujudkan suatu peningkatan kualitas hidup dalam setiap aktivitas fisik.

Kebugaran jasmani merupakan kemampuan atau kesanggupan seseorang dalam menjalankan aktivitas sehari- hari yang pada akhirnya tidak akan mengalami kelelahan yang berarti. Kebugaran jasmani juga mempunyai banyak manfaat diantaranya berhubungan dengan jantung, pembuluh darah, paru- paru dan agar otot dalam tubuh kita dapat berfungsi secara efisien dan optimal. Adapun proses agar Kebugaran jasmani ini dapat dicapai adalah dengan banyak melakukan aktivitas gerak fisik atau berolahraga.

Menurut Sudoso dalam Efwilza (2002) mengemukakan "kesegaran jasmani lebih menitik beratkan kepada physical fitness yaitu kemampuan tubuh untuk menyesuaian fungsi alat-alat dalan fisilogis terhadap lingkungan (ketinggian, kelembaban, suhu dan sebagainya)". Dengan demikian dapat disimpulkan bahwa kesegaran jasmani adalah aspek-aspek kemampuan fisik yang menunjang kesuksesan siswa dalam melakukan berbagai aktivitas dalam kehidupan sehari-hari tanpa mengakibatkan kelelahan yang berarti.

Cara ini dapat dilakukan dimana saja, baik pada pembelajaran penjas maupun di luar jam pembelajaran penjasorkes. Diantaranya dengan cara berjalan kaki atau lari- lari kecil sebelum pergi ke sekolah atau pada sore hari, melakukan peregangan ringan dan senamsenam kecil. Di samping itu, untuk mencapai Kebugaran jasmani yang baik, seseorang tidak hanya melakukan aktivitas fisik saja namun juga harus di imbangi dengan makanan yang cukup bergizi.

Berdasarkan penjelasan di atas bahwa dengan keadaan tingkat Kebugaran jasmani yang dikategorikan sedang dan kurang, Siswa SD Negeri 11 Pasakiat Taileleu akan kesulitan dalam mengatasi kelelahan tubuh yang diakibatkan oleh aktivitas tubuh sehari- hari. Untuk itulah untuk kedepannya di harapkan Guru Penjasorkes dan Kepala Sekolah, serta Orang Tua dan pemerintah agar dapat lebih memperhatikan tingkat Kebugaran jasmani siswa.

Menurut Corbin dan Arsil (1999) menyatakan bahwa "kecepatan adalah kemampuan untuk melangkah dari satu tempat ketempat lainnya dalam waktu yang singkat". Dari pengamatan tersebut peneliti temukan siswa di sekolah tersebut memiliki kesegaran jasmani yang kurang baik. Hal tersebut banyak dapat dilihat dari keadaan siswa tersebut ketika dalam proses belajar mengajar. Siswa kebanyakan kurang semangat dalam belajar, banyak siswa yang tidur pada jam pelajaran berlangsung.

Dengan Kebugaran jasmani yang baik, maka seseorang akan mudah dalam melaksanakan dan menyelesaikan suatu kegiatan. Selain itu apabila seseorang sudah memiliki Kebugaran jasmani yang baik, maka dengan sendirinya menciptakan pribadi yang baik pula, baik dari sikap, perkataan, disiplin, dan lain sebagainya. Dengan Kebugaran jasmani seseorang juga akan mempunyai badan yang sehat, segar dan bugar, sehingga tidak merasa lelah dalam beraktivitas.

\section{KESIMPULAN}


Berdasarkan hasil penelitian tentang perbedaan tingkat Kebugaran jasmani Siswa SD Negeri 11 Pasakiat Taileleu, maka dapat ditarik kesimpulan bahwa: tingkat Kebugaran jasmani Siswa SD Negeri 11 Pasakiat Taileleu berada pada klasifikasi sedangBerdasarkan temuan tersebut dapat disarankan kepada; 1) Kepala SD Negeri 11 Pasakiat Taileleu dalam meningkatkan tingkat Kebugaran jasmani diharapkan agar memberikan dukungan, baik itu dalam penyediaan sarana dan prasarana olahraga, maupun dukungan moril, dan diharapkan juga kepala sekolah bisa bekerjasama dengan berbagai pihak dalam hal penyediaan sarana dan prasarana olahraga.

Selanjutnya kepada Guru penjasorkes agar terus memotivasi siswa agar mau melakukan aktivitas gerak, dan juga menciptakan pola latihan olahraga yang bervariasi. Siswa SD Negeri 11 Pasakiat Taileleu agar terus meningkatkan Kebugaran jasmani salah satunya dengan meluangkan waktu untuk berolahraga. 4) Orang tua siswa agar lebih meningkatkan perhatian terhadap anaknya, baik dengan memotivasi, dan juga memberikan contoh tentang pola hidup sehat, serta dalam hal penguatan mental dan pengawasan gizi anak. Dan 5) Kepala Dinas Pendidikan agar memberikan dukungan baik secara moril dan materil, yaitu dalam penyediaan sarana dan prasarana, demi kelancaran proses belajar mengajar pada umumnya, dan kegiatan belajar mengajar penjasorkes khususnya

\section{DAFTAR RUJUKAN}

Arsil. 1999. Pembinaan Kondisi Fisik. Padang: Fakultas Ilmu Keolahragaan Universitas Negeri Padang.

Efwilza. 2002. Perbedaan Tingkat Kesegaran Jasmani Murid SD No 16 di Kawasan Pertambangan Batu Bara Ombilin Dengan Murid SD no 20 Luar Kawasan Batu Bara Ombilin Kota Sawah Lunto (Skripsi). Padang.

Getchel, Bud. 1983. Physical Fitness A Way Of Life. New York: Jhon Willey

Napitupulu. Dr, W.P. (1977). Penilaian Kesegaran Jasmani dengan Test A.C.S.P.F.T,Jakarta : Pusat Kesegaran Jasmani dan ReaksiDepartemen P dan K

Suharsimi, Arikunto. 1998. Prosedur Penelitian Suatu Pendekatan Praktek. Jakarta: Bina Aksara.

Sutarman. 1975. Pengertian Kesegaran Jasmanidan Tes Kardiorespiratori (Konsept Of Sport Science) ed.sie Swamp dan Mery W, sie. Jakarta: Pusat Ilmu Keolahragaan KONI

Undang-Undang Republik Indonesia No. 20 Tahun 2003 Tentang Sistem Pendidikan Nasional 2003. Jakarta: BP Cipta Jaya

UNP. 2010. Buku Panduan Penulisan Tugas Akhir/Skripsi UNP. Padang: UNP 